\title{
Influence of Foliar Application of Secondary and Micronutrient Combinations on Plant Height and Plant Canopy Spread Attributes Pertaining to Guava cv. Allahabad Safeda
}

\author{
N.S. Sushmitha ${ }^{1}$ Jagannath $^{2}$, A. Mamatha ${ }^{3 *}$ and U. Premchand ${ }^{4}$ \\ ${ }^{1}$ Department of Horticulture, Tirthahalli, Karnataka - 577432, India \\ ${ }^{2}$ Department (Retired), Department of Fruit science. College of horticulture, Bangalore, \\ Karnataka -560065, India \\ ${ }^{3}$ Vegetable Research Station, ARI Campus, Rajendranagar, Hyderabad, \\ Telangana - 500030, India \\ ${ }^{4}$ Department of Plant Pathology, College of horticulture, Bagalkot, \\ Karnataka - 587104, India \\ *Corresponding author
}

\section{A B S T R A C T}

\section{Keywords \\ Guava, Plant height, Plant canopy, Secondary nutrients, Foliar applications \\ Article Info \\ Accepted: 15 April 2019 Available Online: 10 May 2019}

\section{Introduction}

Guava (Psidium guajava L.) is one of the most popular fruit crop cultivated all over India. It is the fourth most important fruit crop in area and production after mango, banana and citrus (Pedapati and Tiwari, 2014). Guava belongs to the family Myrtaceae and is classified under the genus Psidium, which contains 150 species, but only Psidium guajava has been exploited commercially. Guava is a native of tropical America, the crop was introduced into India during $17^{\text {th }}$ century by the Portuguese. It is the fruit that has been often referred to as "apple of tropics." Total area under guava production in India is $2,36,000$ ha with a production of $31,98,000 \mathrm{MT}$ and Maharastra is the leading 
state in guava production with 0.31 MT followed by Madhya Pradesh and Uttar Pradesh (Anon, 2014).

In recent years, several nutritional disorders in guava have been noticed, because of imbalanced nutrient management. A large number of guava orchards have become chronically affected by bronzing. In view of this, Foliar feeding of nutrients to fruit plants has gained much importance in recent years, which is quite economical and obviously an ideal way of evading the problems of nutrient disorder and supplementing the fertilizers.

\section{Materials and Methods}

The present investigation was conducted at Regional Horticultural Research and Extension Centre, Bengaluru during August 2014 to March 2015. Geographically positioned between $12^{0} 58$ latitude North, $77^{0} 11^{\prime}$ longitude East and altitude 930 meters above than mean sea level and is situated in the Eastern dry zone of Karnataka.

The experiment was conducted on well established orchard of 4 years old Allahabad Safeda guava trees which are planted at $6 \times 3$ $\mathrm{m}$ spacing and exposed to identical conditions of weather, having identical soil and cultural operations.

All the plants were supplied with uniform application of manures, fertilizers, prophylactic plant protection measures and irrigation at regular intervals. The experiment was laid out in Randomized Complete Block Design (RCBD) with fourteen treatments replicated thrice. Recommended dose of fertilizer applied 100:40:75 g NPK and $25 \mathrm{Kg}$ FYM per tree. The treatment details are given in Table 1. The foliar application of these treatments as per the plan was made at 8 sprays per season at an interval of 15 days.
Observations on plant height and plant canopy spread

Observations were recorded on three plants for each treatment, and growth parameters were recorded at monthly interval. For plant height, from collar region to the apical tip portion of the plant was recorded using measuring scale and expressed in centimetre. In plant canopy spread, the distance from one end of leaf tip to other end of leaf tip in both North- South and East- West direction was measured using measuring scale, by multiplying the North- South and East- West distance plant canopy spread was calculated and expressed in meter square.

\section{Statistical Analysis}

The data on plant height and plant canopy spread during the course of investigation were statistically analysed, applying the technique of analysis of variance suggested by Panse and Sukhatme (1985). Wherever, the treatment differences were found significant, (F-test) critical difference was worked out at five per cent probability level. The treatment differences that were not significant were denoted by "NS".

\section{Results and Discussion}

The data on effect of foliar application of secondary and micronutrients on growth parameters viz., plant height $(\mathrm{cm})$, plant canopy spread (m2) of Guava Cv. Allahabad Safeda from 30 days to 240 days after foliar spray at monthly intervals are presented here which showed the significance differences among the treatments.

\section{Plant height (cm)}

The data pertaining to plant height of Guava cv. Allahabad Safeda recorded at monthly intervals as influenced by foliar application of 
secondary and micronutrients are presented in Table 2. The plant height at all stages after foliar spray showed significant differences.

The plant height $(218.53 \mathrm{~cm})$ was significantly more with application of RDF+ foliar spray of $\mathrm{Zn}+\mathrm{Mg}+\mathrm{Mn} @ 0.75 \%+\mathrm{Cu}$ $+\mathrm{Fe} @ 0.5 \%$ + MAP 0.5\% $\left(\mathrm{T}_{13}\right)$ followed by $\mathrm{T}_{9}(210.63 \mathrm{~cm}), \mathrm{T}_{11}(208.43 \mathrm{~cm})$ and $\mathrm{T}_{12}$ $(207.26 \mathrm{~cm})$ at 30 days after foliar spray. Similar, significant trend was observed at 60 $(221.46 \mathrm{~cm}), 90(223.13 \mathrm{~cm}), 120(225.96$ $\mathrm{cm}), 150(229.23 \mathrm{~cm}), 180(232.40 \mathrm{~cm}), 210$ $(235.50 \mathrm{~cm})$ and $240(238.20 \mathrm{~cm})$ days after spraying.

This was followed by RDF+ foliar spray of $\mathrm{Zn}+\mathrm{Mg}+\mathrm{Mn} @ 0.75 \%$ along with $\mathrm{Cu}+\mathrm{Fe}$ @ $0.5 \%\left(\mathrm{~T}_{9}\right)$ during all the observed days and was at par with $\mathrm{T}_{11}$ and $\mathrm{T}_{12}$ at 30 days, $\mathrm{T}_{8}, \mathrm{~T}_{10}$, $\mathrm{T}_{11}$ and $\mathrm{T}_{12}$ at 60, 90, 120 and 150 days after spray, while at 180, 210 and 240 days of spray $\mathrm{T}_{8}, \mathrm{~T}_{11}$ and $\mathrm{T}_{12}$ were at par with $\mathrm{RDF}+$ foliar spray of $\mathrm{Zn}+\mathrm{Mg}+\mathrm{Mn} @ 0.75 \%$ along with $\mathrm{Cu}+\mathrm{Fe} @ 0.5 \%$. The minimum plant height was recorded in control $\left(\mathrm{T}_{14}\right)$ at all stages (Table 2).

The data on 240 days after foliar spray indicated that plant height differed significantly among the treatments. The application of $\mathrm{RDF}+$ foliar spray of $\mathrm{Zn}+\mathrm{Mg}$ +Mn@0.75\%+Cu+Fe@0.5\%+.MAP $0.5 \%\left(\mathrm{~T}_{13}\right)$ recorded the maximum plant height $(238.20 \mathrm{~cm})$ and minimum plant height $(199.03 \mathrm{~cm})$ was recorded in $\mathrm{RDF}+$ foliar spray of $\mathrm{Zn}+\mathrm{DAP} @ 0.5 \%\left(\mathrm{~T}_{14}\right)$.

\section{Plant canopy spread $\left(\mathbf{m}^{2}\right)$}

The plants canopy spread of guava cv. Allahabad Safeda (Table 3) as influenced by application of RDF+ foliar spray of $\mathrm{Zn}+\mathrm{Mg}$ + Mn@0.75\%+Cu +Fe@0.5\% + MAP $0.5 \%\left(\mathrm{~T}_{13}\right)$ recorded the maximum plant canopy spread $\left(4.51 \mathrm{~m}^{2}\right)$, which was followed by $\mathrm{T}_{9}\left(4.36 \mathrm{~m}^{2}\right)$ at 30 days after foliar spray. Likewise, 60 days after foliar spray also $\mathrm{T}_{13}$ $\left(4.59 \mathrm{~m}^{2}\right)$ was followed by $\mathrm{T}_{9}\left(4.42 \mathrm{~m}^{2}\right)$.

Similarly, the plant canopy spread was significantly superior in treatment 13 at 90 days $\left(4.67 \mathrm{~m}^{2}\right), 120$ days $\left(4.74 \mathrm{~m}^{2}\right), 150$ days $\left(4.81 \mathrm{~m}^{2}\right), 180$ days $\left(4.86 \mathrm{~m}^{2}\right), 210$ days $(4.91$ $\mathrm{m}^{2}$ ) and 240 days $\left(5.01 \mathrm{~m}^{2}\right)$, this was followed by $\mathrm{RDF}+$ foliar spray of $\mathrm{Zn}+\mathrm{Mg}+\mathrm{Mn} @$ $0.75 \%$ along with $\mathrm{Cu}+\mathrm{Fe} @ 0.5 \%\left(\mathrm{~T}_{9}\right)$ at different stages of observation and also at par with $\mathrm{T}_{11}$ at 30, 60, 90, 120 and 150 days after spray. The minimum plant canopy spread $\left(3.05 \mathrm{~m}^{2}\right)$ was recorded in control $\left(\mathrm{T}_{14}\right)$ at 240 days after foliar spray (Table 3 ).

Application of RDF+ foliar spray of $\mathrm{Zn}+\mathrm{Mg}$ + Mn@0.75\% + Cu +Fe@0.5\% + MAP $0.5 \%\left(\mathrm{~T}_{13}\right)$ recording significantly maximum plant canopy spread $\left(5.01 \mathrm{~m}^{2}\right)$. Whereas, minimum plant canopy spread $\left(3.05 \mathrm{~m}^{2}\right)$ was recorded in $\left(\mathrm{T}_{14}\right) \mathrm{RDF}+$ foliar spray of $\mathrm{Zn}+$ DAP@ $0.5 \%$.

Hence the application of recommended dose of fertilizer along with foliar application of $\mathrm{Zn}$ + Mg+Mn@0.75\%+Cu+Fe@0.5\%+ MAP $0.5 \%$ significantly influenced the plant height, plant canopy spread (N-S and E-W).

The increase in growth parameters such as plant height, plant canopy spread (N-S and E$\mathrm{W})$ in the present investigation might be due to the foliar application of micronutrients which may have influenced the photosynthetic compounds in the plant tissue which may be involved in the synthesis of tryptophan, a precursor of IAA, so ultimately increasing the vegetative growth of the plant. Similar result was observed by Yadav et al., (2010) in banana and Shamashad et al., (2009) in aonla. 
Table.1 Treatment details

\begin{tabular}{|l|l|}
\hline Treatments No. & Treatments \\
\hline $\mathbf{T}_{\mathbf{I}}$ & RDF+ foliar spray of MAP 0.5\% \\
\hline $\mathbf{T}_{\mathbf{2}}$ & RDF+ foliar spray of $\mathrm{Zn}+\mathrm{Mg}+\mathrm{Mn} @ 0.5 \%$ \\
\hline $\mathbf{T}_{\mathbf{3}}$ & RDF+ foliar spray of $\mathrm{Zn}+\mathrm{Mg}+\mathrm{Mn} @ 0.5 \%+\mathrm{MAP} 0.5 \%$ \\
\hline $\mathbf{T}_{\mathbf{4}}$ & RDF+ foliar spray of $\mathrm{Zn}+\mathrm{Mg}+\mathrm{Mn} @ 0.75 \%$ \\
\hline $\mathbf{T}_{\mathbf{5}}$ & RDF+ foliar spray of $\mathrm{Zn+Mg}+\mathrm{Mn} @ 0.75 \%+\mathrm{MAP} 0.5 \%$ \\
\hline $\mathbf{T}_{\mathbf{6}}$ & RDF+ foliar spray of $\mathrm{Zn}+\mathrm{Mg}+\mathrm{Mn} @ 0.5 \%+\mathrm{Cu}+\mathrm{Fe} @ 0.25 \%$ \\
\hline $\mathbf{T}_{\mathbf{7}}$ & RDF+ foliar spray of $\mathrm{Zn}+\mathrm{Mg}+\mathrm{Mn} @ 0.75 \%+\mathrm{Cu}+\mathrm{Fe} @ 0.25 \%$ \\
\hline $\mathbf{T}_{\mathbf{8}}$ & RDF+ foliar spray of $\mathrm{Zn}+\mathrm{Mg}+\mathrm{Mn} @ 0.5 \%+\mathrm{Cu}+\mathrm{Fe} @ 0.5 \%$ \\
\hline $\mathbf{T}_{\mathbf{9}}$ & RDF+ foliar spray of $\mathrm{Zn}+\mathrm{Mg}+\mathrm{Mn} @ 0.75 \%+\mathrm{Cu}+\mathrm{Fe} @ 0.5 \%$ \\
\hline $\mathbf{T}_{\mathbf{1 0}}$ & RDF+ foliar spray of $\mathrm{Zn}+\mathrm{Mg}+\mathrm{Mn} @ 0.5 \%+\mathrm{Cu}+\mathrm{Fe} @ 0.25 \%+\mathrm{MAP} 0.5 \%$ \\
\hline $\mathbf{T}_{\mathbf{1 1}}$ & RDF+ foliar spray of $\mathrm{Zn}+\mathrm{Mg}+\mathrm{Mn} @ 0.75 \%+\mathrm{Cu}+\mathrm{Fe} @ 0.25 \%+\mathrm{MAP} 0.5 \%$ \\
\hline $\mathbf{T}_{\mathbf{1 2}}$ & RDF+ foliar spray of $\mathrm{Zn}+\mathrm{Mg}+\mathrm{Mn} @ 0.5 \%+\mathrm{Cu}+\mathrm{Fe} @ 0.5 \%+\mathrm{MAP} 0.5 \%$ \\
\hline $\mathbf{T}_{\mathbf{1 3}}$ & RDF+ foliar spray of $\mathrm{Zn}+\mathrm{Mg}+\mathrm{Mn} @ 0.75 \%+\mathrm{Cu}+\mathrm{Fe} @ 0.5 \%+\mathrm{MAP} 0.5 \%$ \\
\hline $\mathbf{T}_{\mathbf{1 4}}$ & RDF+ foliar spray of $\mathrm{Zn}+\mathrm{DAP} @ 0.5 \%(\mathrm{Control})$ \\
\hline
\end{tabular}

Table.2 Effect of foliar application of secondary and micronutrient combinations on plant height of guava cv. Allahabad Safeda

\begin{tabular}{|c|c|c|c|c|c|c|c|c|}
\hline \multirow[t]{2}{*}{ Treatments } & \multicolumn{8}{|c|}{ Plant height $(\mathrm{cm})$ at days after spray } \\
\hline & 30 & 60 & 90 & 120 & 150 & 180 & 210 & 240 \\
\hline $\mathbf{T}_{1}$ & 196.00 & 198.50 & 200.90 & 203.56 & 205.76 & 209.26 & 211.63 & 214.70 \\
\hline $\mathbf{T}_{2}$ & 199.10 & 202.63 & 204.76 & 207.00 & 208.83 & 211.76 & 214.06 & 216.76 \\
\hline $\mathbf{T}_{3}$ & 200.56 & 204.00 & 206.16 & 208.86 & 210.56 & 212.96 & 215.40 & 217.76 \\
\hline $\mathbf{T}_{4}$ & 201.80 & 204.16 & 205.86 & 208.63 & 210.53 & 213.70 & 216.73 & 219.03 \\
\hline $\mathbf{T}_{5}$ & 202.46 & 205.70 & 207.53 & 210.00 & 212.13 & 214.83 & 217.76 & 220.33 \\
\hline $\mathbf{T}_{6}$ & 203.16 & 206.06 & 208.56 & 211.10 & 213.23 & 215.26 & 217.63 & 220.40 \\
\hline $\mathbf{T}_{7}$ & 204.46 & 207.23 & 209.63 & 212.10 & 215.00 & 217.26 & 219.86 & 221.76 \\
\hline $\mathbf{T}_{8}$ & 206.16 & 208.86 & 210.96 & 213.56 & 216.20 & 218.50 & 221.83 & 224.16 \\
\hline $\mathbf{T}_{9}$ & 210.63 & 212.26 & 214.40 & 216.86 & 219.56 & 222.13 & 225.20 & 227.73 \\
\hline$T_{10}$ & 206.66 & 209.63 & 211.60 & 213.76 & 215.46 & 217.96 & 220.80 & 223.10 \\
\hline $\mathbf{T}_{11}$ & 208.43 & 211.36 & 213.90 & 215.80 & 218.30 & 221.70 & 224.73 & 227.23 \\
\hline$T_{12}$ & 207.26 & 209.66 & 212.10 & 214.10 & 218.26 & 220.60 & 223.20 & 224.76 \\
\hline$T_{13}$ & 218.53 & 221.46 & 223.13 & 225.96 & 229.23 & 232.40 & 235.50 & 238.20 \\
\hline$T_{14}$ & 181.50 & 184.23 & 186.16 & 188.56 & 191.43 & 193.93 & 196.36 & 199.03 \\
\hline S. Em. \pm & 1.28 & 1.52 & 1.51 & 1.46 & 1.42 & 1.37 & 1.41 & 1.40 \\
\hline C.D. at $5 \%$ & 3.72 & 4.43 & 4.41 & 4.24 & 4.15 & 3.99 & 4.12 & 4.07 \\
\hline
\end{tabular}

$\mathrm{T}_{1}-\mathrm{RDF}+$ foliar spray of MAP $0.5 \%$

$\mathrm{T}_{2}-\mathrm{RDF}+$ foliar spray of $\mathrm{Zn}+\mathrm{Mg}+\mathrm{Mn} @ 0.5 \%$

$\mathrm{T}_{3}$ - RDF+ foliar spray of $\mathrm{Zn}+\mathrm{Mg}+\mathrm{Mn} @ 0.5 \%+\mathrm{MAP} 0.5 \%$

$\mathrm{T}_{4}-\mathrm{RDF}+$ foliar spray of $\mathrm{Zn}+\mathrm{Mg}+\mathrm{Mn} @ 0.75 \%$

$\mathrm{T}_{5^{-}} \mathrm{RDF}+$ foliar spray of $\mathrm{Zn}+\mathrm{Mg}+\mathrm{Mn} @ 0.75 \%+\mathrm{MAP} 0.5 \%$

$\mathrm{T}_{6}-\mathrm{RDF}+$ foliar spray of $\mathrm{Zn}+\mathrm{Mg}+\mathrm{Mn} @ 0.5 \%+\mathrm{Cu}+\mathrm{Fe} @ 0.25 \%$

$\mathrm{T}_{7}$ - RDF+ foliar spray of $\mathrm{Zn}+\mathrm{Mg}+\mathrm{Mn} @ 0.75 \%+\mathrm{Cu}+\mathrm{Fe} @ 0.25 \%$

$\mathrm{T}_{8^{-}} \mathrm{RDF}+$ foliar spray of $\mathrm{Zn}+\mathrm{Mg}+\mathrm{Mn} @ 0.5 \%+\mathrm{Cu}+\mathrm{Fe} @ 0.5 \%$

$\mathrm{T}_{9}-\mathrm{RDF}+$ foliar spray of $\mathrm{Zn}+\mathrm{Mg}+\mathrm{Mn} @ 0.75 \%+\mathrm{Cu}+\mathrm{Fe} @ 0.5 \%$

$\mathrm{T}_{10^{-}} \mathrm{RDF}+$ foliar spray of $\mathrm{Zn}+\mathrm{Mg}+\mathrm{Mn} @ 0.5 \%+\mathrm{Cu}+\mathrm{Fe} @ 0.25 \%+\mathrm{MAP} 0.5 \%$

$\mathrm{T}_{11}$ - RDF+ foliar spray of $\mathrm{Zn}+\mathrm{Mg}+\mathrm{Mn} @ 0.75 \%+\mathrm{Cu}+\mathrm{Fe} @ 0.25 \%+\mathrm{MAP} 0.5 \%$

$\mathrm{T}_{12}-\mathrm{RDF}+$ foliar spray of $\mathrm{Zn}+\mathrm{Mg}+\mathrm{Mn} @ 0.5 \%+\mathrm{Cu}+\mathrm{Fe} @ 0.5 \%+\mathrm{MAP} 0.5 \%$

$\mathrm{T}_{13}$ - RDF+ foliar spray of $\mathrm{Zn}+\mathrm{Mg}+\mathrm{Mn} @ 0.75 \%+\mathrm{Cu}+\mathrm{Fe} @ 0.5 \%+\mathrm{MAP} 0.5 \%$

$\mathrm{T}_{14^{-}}$Control - RDF+ foliar spray of Zn+DAP @ $0.5 \%$ 
Int.J.Curr.Microbiol.App.Sci (2019) 8(5): 1828-1833

Table.3 Effect of foliar application of secondary and micronutrient combinations on plant canopy spread of guava cv. Allahabad safeda

\begin{tabular}{|l|l|l|l|l|l|l|l|l|}
\hline Treatments & \multicolumn{9}{|l|}{ Plant canopy spread $\mathbf{( m}^{\mathbf{2}}$ ) at days after spray } \\
\cline { 2 - 9 } & $\mathbf{3 0}$ & $\mathbf{6 0}$ & $\mathbf{9 0}$ & $\mathbf{1 2 0}$ & $\mathbf{1 5 0}$ & $\mathbf{1 8 0}$ & $\mathbf{2 1 0}$ & $\mathbf{2 4 0}$ \\
\hline $\mathbf{T}_{\mathbf{1}}$ & 2.65 & 2.70 & 2.80 & 2.89 & 2.95 & 3.02 & 3.06 & 3.12 \\
\hline $\mathbf{T}_{\mathbf{2}}$ & 2.71 & 2.77 & 2.90 & 2.99 & 3.03 & 3.09 & 3.12 & 3.18 \\
\hline $\mathbf{T}_{\mathbf{3}}$ & 3.30 & 3.37 & 3.40 & 3.47 & 3.50 & 3.55 & 3.62 & 3.65 \\
\hline $\mathbf{T}_{\mathbf{4}}$ & 3.35 & 3.45 & 3.51 & 3.58 & 3.63 & 3.68 & 3.72 & 3.79 \\
\hline $\mathbf{T}_{\mathbf{5}}$ & 3.92 & 3.96 & 4.06 & 4.12 & 4.20 & 4.25 & 4.30 & 4.36 \\
\hline $\mathbf{T}_{\mathbf{6}}$ & 3.51 & 3.60 & 3.66 & 3.73 & 3.79 & 3.85 & 3.89 & 4.01 \\
\hline $\mathbf{T}_{\mathbf{7}}$ & 4.09 & 4.16 & 4.22 & 4.25 & 4.32 & 4.37 & 4.44 & 4.47 \\
\hline $\mathbf{T}_{\mathbf{8}}$ & 4.10 & 4.20 & 4.26 & 4.32 & 4.37 & 4.43 & 4.47 & 4.53 \\
\hline $\mathbf{T}_{\mathbf{9}}$ & 4.36 & 4.42 & 4.47 & 4.53 & 4.57 & 4.62 & 4.67 & 4.74 \\
\hline $\mathbf{T}_{\mathbf{1 0}}$ & 3.70 & 3.80 & 3.83 & 3.88 & 3.94 & 4.01 & 4.09 & 4.13 \\
\hline $\mathbf{T}_{\mathbf{1 1}}$ & 4.33 & 4.36 & 4.42 & 4.48 & 4.52 & 4.55 & 4.60 & 4.64 \\
\hline $\mathbf{T}_{\mathbf{1 2}}$ & 4.14 & 4.24 & 4.29 & 4.34 & 4.40 & 4.45 & 4.50 & 4.55 \\
\hline $\mathbf{T}_{\mathbf{1 3}}$ & 4.51 & 4.59 & 4.67 & 4.74 & 4.81 & 4.86 & 4.91 & 5.01 \\
\hline $\mathbf{T}_{\mathbf{1 4}}$ & 2.56 & 2.61 & 2.70 & 2.81 & 2.89 & 2.94 & 3.00 & 3.05 \\
\hline $\mathbf{S . ~}_{\mathbf{E m}} \mathbf{\pm}$ & 0.04 & 0.02 & 0.02 & 0.01 & 0.01 & 0.02 & 0.01 & 0.02 \\
\hline $\mathbf{C . D}_{\mathbf{n}}$ at 5\% & 0.12 & 0.08 & 0.08 & 0.05 & 0.05 & 0.06 & 0.05 & 0.06 \\
\hline
\end{tabular}

$\mathrm{T}_{1}-\mathrm{RDF}+$ foliar spray of MAP $0.5 \%$

$\mathrm{T}_{2}-\mathrm{RDF}+$ foliar spray of $\mathrm{Zn}+\mathrm{Mg}+\mathrm{Mn} @ 0.5 \%$

$\mathrm{T}_{3}-\mathrm{RDF}+$ foliar spray of $\mathrm{Zn}+\mathrm{Mg}+\mathrm{Mn} @ 0.5 \%+\mathrm{MAP} 0.5 \%$

$\mathrm{T}_{4}-\mathrm{RDF}+$ foliar spray of $\mathrm{Zn}+\mathrm{Mg}+\mathrm{Mn} @ 0.75 \%$

$\mathrm{T}_{5}-\mathrm{RDF}+$ foliar spray of $\mathrm{Zn}+\mathrm{Mg}+\mathrm{Mn} @ 0.75 \%+\mathrm{MAP} 0.5 \%$

$\mathrm{T}_{6}-\mathrm{RDF}+$ foliar spray of $\mathrm{Zn}+\mathrm{Mg}+\mathrm{Mn} @ 0.5 \%+\mathrm{Cu}+\mathrm{Fe} @ 0.25 \%$

$\mathrm{T}_{7}-\mathrm{RDF}+$ foliar spray of $\mathrm{Zn}+\mathrm{Mg}+\mathrm{Mn} @ 0.75 \%+\mathrm{Cu}+\mathrm{Fe} @ 0.25 \%$

$\mathrm{T}_{8}-\mathrm{RDF}+$ foliar spray of $\mathrm{Zn}+\mathrm{Mg}+\mathrm{Mn} @ 0.5 \%+\mathrm{Cu}+\mathrm{Fe} @ 0.5 \%$

$\mathrm{T}_{9}-\mathrm{RDF}+$ foliar spray of $\mathrm{Zn}+\mathrm{Mg}+\mathrm{Mn} @ 0.75 \%+\mathrm{Cu}+\mathrm{Fe} @ 0.5 \%$

$\mathrm{T}_{10}-\mathrm{RDF}+$ foliar spray of $\mathrm{Zn}+\mathrm{Mg}+\mathrm{Mn} @ 0.5 \%+\mathrm{Cu}+\mathrm{Fe} @ 0.25 \%+\mathrm{MAP} 0.5 \%$

$\mathrm{T}_{11}-\mathrm{RDF}+$ foliar spray of $\mathrm{Zn}+\mathrm{Mg}+\mathrm{Mn} @ 0.75 \%+\mathrm{Cu}+\mathrm{Fe} @ 0.25 \%+\mathrm{MAP} 0.5 \%$

$\mathrm{T}_{12}-\mathrm{RDF}+$ foliar spray of $\mathrm{Zn}+\mathrm{Mg}+\mathrm{Mn} @ 0.5 \%+\mathrm{Cu}+\mathrm{Fe} @ 0.5 \%+\mathrm{MAP} 0.5 \%$

$\mathrm{T}_{13}-\mathrm{RDF}+$ foliar spray of $\mathrm{Zn}+\mathrm{Mg}+\mathrm{Mn} @ 0.75 \%+\mathrm{Cu}+\mathrm{Fe} @ 0.5 \%+\mathrm{MAP} 0.5 \%$

$\mathrm{T}_{14^{-}}$Control - RDF+ foliar spray of Zn+DAP @ $0.5 \%$

Further, application of proper dose of micronutrients, play an important functional role in chlorophyll synthesis and development of cells in meristemetic tissues (Shekar et al., 2010) in papaya, while Ram and Bose (2000) have indicated that combination of micronutrients, helps to increase the plant growth since zinc is an activator of enzyme, involve in the protein synthesis and had direct effect on the level of auxin in mandarin orange plants.

\section{References}

Anonymous (2014) Indian Horticulture Database-2014, Area and production of Horticultural crops- all India (201314), Ministry of Agriculture, Government of India.

Panse, VG., and Sukhatme PV (1985) Statistical methods for agricultural workers. Indian council of 
agricultural research, New Delhi.

Pedapati, A., and Tiwari RB (2014) Effect of different osmotic pre-treatments on weight loss, yield and moisture loss in osmotically dehydrated guava. Journal of Agricultural research 1(1): 49-54.

Ram, RA., and Bose TK (2000) Effect of foliar application of magnesium and micronutrients on growth, yield and fruit quality of mandarin orange (Citrus reticulata Blanco). Indian Jounal of Horticulrure 57(3): 215-220.

Shamashad, K., Singh HK, Vishwanath and Bhanu P (2009) Impact of foliar application of micro-nutrients and thiourea on growth, fruit yield and quality of aonla. Annuals of Horticulture 2(1): 83-85.

Shekar, C., Yadav AL, Singh HK and Singh MK (2010) Influence of micronutrients on plant growth, yield and quality of papaya fruit (Carica papaya L.) cv. Washington. Asian Journal of Horticulture 5(2): 326-329.

Yadav, MK., Patel NL, Parmar BR. Kirtibarthan and Singh P (2010) Effect of micronutrients on growth and crop duration of banana cv. Grand Naine. Progressive Horticulture 42(2): 162164.

\section{How to cite this article:}

Sushmitha, N.S., Jagannath, A. Mamatha and Premchand, U. 2019. Influence of Foliar Application of Secondary and Micronutrient Combinations on Plant Height and Plant Canopy Spread Attributes Pertaining to Guava cv. Allahabad Safeda. Int.J.Curr.Microbiol.App.Sci. 8(05): 1828-1833. doi: https://doi.org/10.20546/ijcmas.2019.805.212 